\title{
Traditional Cultural Expressions and International Intellectual Property Law $\uparrow$
}

LiLY MARTINET $^{1}$

This presentation draws on my doctoral research, which was conducted on traditional cultural expressions in international law. ${ }^{2}$ This subject still fills me with passion even after having spent many years studying it. To sum up my Ph.D. thesis in a sentence, I studied how international law embraces traditional dances, songs, handicrafts, designs, and rituals. Very diverse fields of laws were relevant for this research, but in the framework of this presentation, the focus was kept on intellectual property. The goal of this presentation was to provide answers to two essential questions. The first question relates to the definition of traditional cultural expressions (I), the second one concerned the reasons underpinning the introduction of this concept in international law (II).

\section{What Are Traditional Cultural Expressions?}

At the beginning of the twenty-first century, the use of the term "traditional cultural expression" spread among several international forums. Although there is no accepted definition in international law of traditional cultural expressions, two instruments mention them expressly. The first instrument, the Convention on the Protection and Promotion of the Diversity of Cultural Expressions (CCD), was adopted in 2005 by the General Conference of the United Nations Educational, Scientific and Cultural Organization (UNESCO). The preamble of the CCD refers twice in passing to traditional cultural expressions. The first occurrence presents traditional cultural expressions as a subset of cultural expressions:

Recognising that the diversity of cultural expressions, including traditional cultural expressions, is an important factor that allows individuals and peoples to express and to share with others their ideas and values. ${ }^{3}$

The second occurrence connects them to minorities and indigenous peoples:

Taking into account the importance of the vitality of cultures, including for persons belonging to minorities and indigenous peoples, as manifested in their freedom to create, disseminate and distribute their traditional cultural expressions and to have access thereto, so as to benefit them for their own development. ${ }^{4}$

The introduction of traditional cultural expressions in the CCD was more symbolic then operational. Recital 13 and 15 of the CDD's preamble only recall freedoms and cultural rights, which are already protected by human rights instruments. Nevertheless, mentioning this concept acknowledges the negotiations taking place in other forums,

$\dagger$ Lecture given at the 37th Annual Course on International Law and Legal Information, Luxembourg, organized by the International Association of Law Libraries, September 30-October 3, 2018.

${ }^{1}$ (C) Lily Martinet 2019. The author is a Senior Research Fellow at the Max Planck Institute Luxembourg for International, European and Regulatory Procedural Law.

${ }^{2}$ This is a revised version of the text of an oral presentation delivered on October 2, 2018 at 37th Annual Course of the International Association of Law Libraries, Law in Luxembourg - Where Local Tradition Meets European and International Innovation, Max Planck Institute Luxembourg for Procedural Law, September 30-October 3, 2018.

${ }^{3} \mathrm{CCD}$, Preamble, recital 13.

${ }^{4}$ Ibid., recital 15. 
especially at the World Intellectual Property Organization (WIPO), and expresses support for the protection of traditional cultural expressions. ${ }^{5}$

The other instrument using traditional cultural expressions as an autonomous legal concept is the United Nations Declaration on the Rights of Indigenous Peoples (UNDRIP) (2007). Article 31.1 of UNDRIP links traditional cultural expressions with cultural heritage and traditional knowledge:

Indigenous peoples have the right to maintain, control, protect and develop their cultural heritage, traditional knowledge and traditional cultural expressions, as well as the manifestations of their sciences, technologies and cultures, including human and genetic resources, seeds, medicines, knowledge of the properties of fauna and flora, oral traditions, literatures, designs, sports and traditional games and visual and performing arts. They also have the right to maintain, control, protect and develop their intellectual property over such cultural heritage, traditional knowledge, and traditional cultural expressions. ${ }^{6}$

The CCD and UNDRIP both associate traditional cultural expressions to the exercise of cultural rights. UNDRIP not only recognizes the right of indigenous peoples to maintain, control, protect, and develop their traditional cultural expressions, but also the intellectual property that relates to them. In addition, article 31 of UNDRIP links traditional cultural expressions with traditional knowledge.

At the same time these instruments were negotiated and adopted, WIPO was working on the legal protection of traditional cultural expressions. In 2000, the General Assembly of WIPO established the Intergovernmental Committee on Intellectual Property and Genetic Resources, Traditional Knowledge and Folklore (IGC) to examine the intellectual property issues that arise in the context of access to genetic resources, the protection of traditional knowledge and expressions of folklore. ${ }^{7}$ This first mandate has evolved, and the IGC Committee is currently overseeing negotiations for an international legal instrument, which will ensure the protection of genetic resources, traditional knowledge, and traditional cultural expressions. ${ }^{8}$

Before the creation of this committee, WIPO had worked on the protection of folklore. After decolonization, African States no longer had copyright laws in force. The Western world, which exports intellectual works, wanted these States to enact copyright legislation and to join the Berne Convention for the Protection of Literary and Artistic Works (hereafter "Berne Convention"), the backbone of international copyright law. To achieve this goal, the United International Bureaux for the Protection of Intellectual Property (BIRPI) ${ }^{9}$ and UNESCO set up a study meeting in 1963 at Brazzaville, to assist African States in defining general principles of copyright protection. ${ }^{10}$ At the time, UNESCO was active in the field of copyright law; it had adopted in 1952 the Universal Copyright Convention.

During this meeting, several delegates raised the issue of the protection of folklore. They pointed out that it was unfair that imported literary and artistic works were protected, whereas African folklore was considered to be a part of the public domain and thus free to be used by anyone. At the closing of the meeting, the delegates adopted a recommendation concerning "Folklore." It provided that copyright in folklore should be "vested in each of the African nations." "In 1967, when the Berne Convention was revised a provision was added to protect folklore. It did not mention folklore as such, but used the paraphrase "unpublished works of unknown authorship." 12 This

5 Tobias Stoll, Sven Mißsling, and Johannes Jürging, "Preamble," in The UNESCO Convention on the Protection and Promotion of the Diversity of Cultural Expressions: Explanatory Notes, ed. Sabine von Schorlemer, and Peter-Tobias Stoll (Heidelberg: Springer Verlag, 2012), 52-53.

${ }^{6}$ For a comprehensive analysis of article 31 of UNDRIP, see Tobias Stoll, "Chapter 11. Intellectual Property and Technologies," in The UN Declaration on the Rights of Indigenous Peoples: a Commentary, ed. Hohmann Jessie and Marc Weller (Oxford: Oxford University Press, 2018), 299-327.

${ }^{7}$ WIPO uses "traditional cultural expressions" and "expressions of folklore" as interchangeable synonyms, see WIPO, ICG, Glossary of Key Terms Related to Intellectual Property and GR, TK and TCE, WIPO/GRTKF/IC/37/INF/7, July 5, 2018. However, the occurrence of "expressions of folklore" has dropped overtime, as reference to "folklore" is thought to carry a negative connotation.

${ }^{8}$ WIPO, IGC, IGC Mandate 2018/2019, 2017, https://www.wipo.int/export/sites/www/tk/en/igc/pdf/igc_mandate_20182019.pdf.

${ }^{9}$ The BIRPI became the World Intellectual Property Organization (WIPO) in 1970.

${ }^{10}$ UNESCO and International Union for the Protection of Literary and Artistic Property, African Study Meeting on Copyright (Brazzaville, 5-10 August 1963): Report, RADA/10.

11 Ibid.

12 Berne Convention, art.15(4). 
provision became a dead letter; India was the only country to notify the Director-General of the designation of a competent authority. ${ }^{13}$

Since the revision of the Berne Convention had settled the issue of folklore, this subject was not brought up again until 1973, when the government of Bolivia submitted a written communication to UNESCO's Director General. The story told is that the government of Bolivia was offended by the worldwide success of the Simon Garfunkel cover of El Condor Passa, a song inspired by traditional Andean melodies. ${ }^{14}$ The government of Bolivia requested in its communication the addition of a protocol to the Universal Copyright Convention declaring all rights in folklore to be the property of the State, on whose territory it had been elaborated or had acquired traditional character. ${ }^{15}$ The communication stressed that folklore was "undergoing the most intensive clandestine commercialisation $[\ldots]$ in a process of commercially oriented transculturation destructive of the traditional cultures." 16

The issue was referred to the Intergovernmental Copyright Committee, who decided to entrust to the UNESCO Secretariat a study on the protection of folklore on an international scale and to report thereon to the Committee and the Executive Committee of the Berne Union. ${ }^{17}$ Several studies and reports followed this first study. In 1977, a committee of experts drew a fundamental distinction between the material protection of folklore, i.e. its conservation and the legal protection, which concerns the regulation of its exploitation. ${ }^{18}$ In 1978 , in accordance with this distinction, the Committees decided to split the examination of the protection of folklore into two branches: the first one, an interdisciplinary approach handed over to UNESCO, the second one, which focused on the copyright aspects was to be examined in association with WIPO. ${ }^{19}$

The first branch grew gradually and came to be intangible cultural heritage. The second branch focusing on the intellectual property aspects involved in the protection of folklore is still currently developing. At first, WIPO collaborated with UNESCO to examine this question. In 1982, they jointly adopted the Model Provisions for National Laws on the Protection of Expressions of Folklore against Illicit Exploitation and other Prejudicial Actions (hereafter "Model Provisions"). The introduction of the term "expressions" was to distinguish the Model Provisions from copyright law, which refers to "works." Despite this intention, the Model Provisions are heavily inspired by copyright as they rely on a system of prior authorizations for publication, reproduction, distribution of copies, and communication to the public of expressions of folklore (section 3).

In Practice, the Model Provisions attained a relative success; only a limited number of States adopted national laws inspired by them and doubts have been expressed on their application. ${ }^{20}$ The Model Provisions were considered as a stepping-stone to adopt a treaty. WIPO and UNESCO prepared a project in 1985, but it was deemed by States too premature to be discussed. To the exception of the WIPO Performances and Phonograms Treaty (1996) that protects the performances of expressions of folklore, from 1985 to the end of the 1990s, WIPO set aside the issue of the protection of expressions of folklore. The emergence of traditional knowledge in international law revived WIPO's activities in connection with traditional cultural expressions and led to the establishment of the IGC Committee. The knowledge acquired in connection with the protection of folklore and expressions of folklore has significantly advanced the understanding of the issues raised by the protection of traditional

13 Agnès Lucas-Schloetter, Protection juridique $d u$ folklore, Jurisclasseur Propriété Littéraire et Artistique, Fasc. 1962 (2009), para. 34.

${ }^{14}$ Valdimar Hafstein, "Célébrer les différences, renforcer la conformité," in Le Patrimoine culturel immatériel: Enjeux d'une nouvelle catégorie, ed. Chiara Bortolotto, Annick Arnaud, and Sylvie Grenet (Paris: Maison des Sciences de l'Homme, 2011), 76-77.

${ }^{15}$ Republic of Bolivia, Communication, 24 April 1973, nºG 01/1006-79.

16 Ibid.

${ }^{17}$ Intergovernmental Copyright Committee and Executive Committee of the International Union for the Protection of Literary and Artistic Works (Berne Union), Consideration of the Possibility of Establishing an International Instrument for the Protection of Folklore, IGC/XR.1(1971)15, 1975, 1.

18 UNESCO, Committee of Experts on the Legal Protection of Folklore, Study of the various aspects involved in the protection of folklore (Tunis, 11-15 July 1977), FOLK/I/3, 1.

${ }^{19}$ Comité intergouvernemental du droit d'auteur, Rapport de la deuxième session extraordinaire (Paris, 18 May 1978), IGC (1971)/II/20, para. 192.

${ }^{20} \mathrm{OMPI}, \mathrm{IGC}$, Analyse globale de la protection juridique des expressions culturelles traditionnelles, 2003, WIPO/GRTKF/ $\mathrm{IC} / 5 / 3$, para. 78 . 


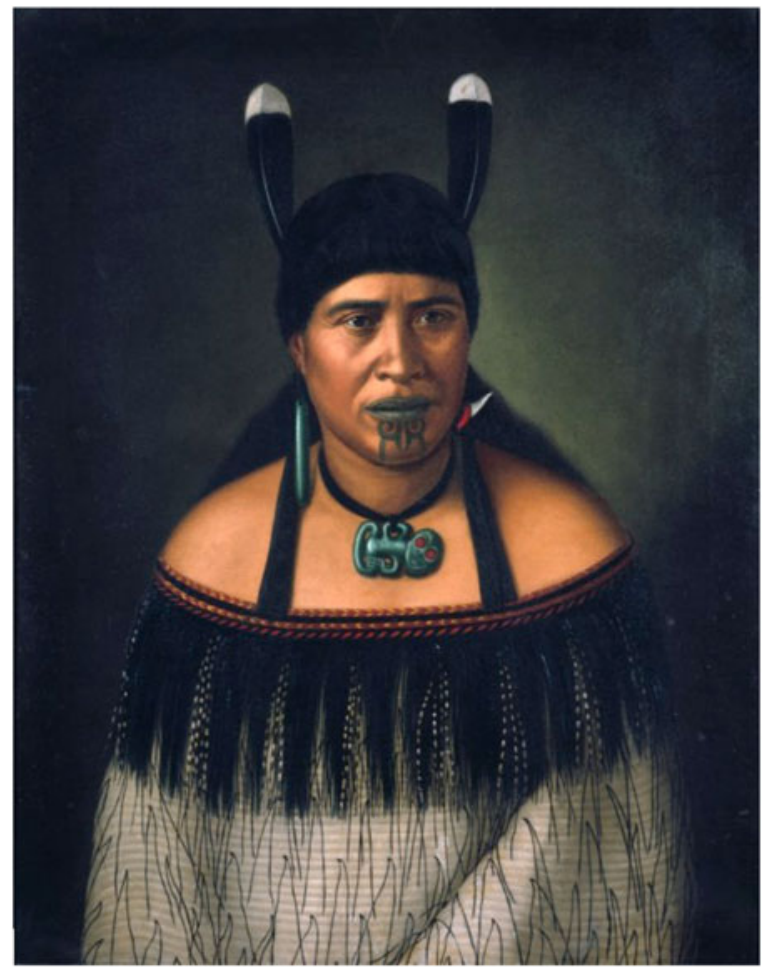

Figure 1. Lindauer, Bohumír Gottfried, 1839-1926: Hinepare of the Ngati Kahungunu tribe of Taakitimu fame. [ca 1890], via Wikimedia Commons

cultural expressions. Although the IGC Committee has achieved significant progress, a consensus has not yet been reached on a definition. The working definition it uses has been changing over time.

Despite the absence of an authoritative definition, it is possible, by studying the CCD, UNDRIP, and the negotiations taking place at the IGC Committee, to put forward three key characters that define traditional cultural expressions: (i) a cultural content, (ii) a collective essence, and (iii) intergenerational transmission. These different features were illustrated in the presentation by using the example of the "Tā Moko," a traditional cultural expression of the Māori. The Tā Moko is a traditional art form of tattooing. ${ }^{21}$

\section{i. A Cultural Content}

As a subset of cultural expressions, traditional cultural expressions "result from the creativity of individuals, groups and societies." 22 As such, they possess a cultural content, which means that they express cultural identities through a symbolic meaning, an artistic dimension, and cultural values. ${ }^{23}$ In the example of the Tā Moko, each pattern has a specific meaning that symbolizes the ancestry, the tribe, and the personal experience of the person bearing the tattoo. ${ }^{24}$ Cultural content is the reason why traditional cultural expressions have been historically associated with copyright. The drafters of UNDRIP and the CCD have shifted this position to a junction point where human rights, intellectual property law, and culture law meet.

Moreover, cultural content is the main characteristic that differentiates traditional cultural expressions from traditional knowledge and intangible cultural heritage. Traditional knowledge is knowledge resulting from intellectual activity in a traditional context; it includes know-how, practices, skills, and innovations. The notion of traditional

${ }^{21}$ See Figure 1.

${ }^{22}$ Art. 4.3 of the CCD.

${ }^{23}$ Art. 4.2 of the CCD.

${ }^{24}$ Waitangi Tribunal, Ko aotearoa tēnei: A Report into Claims Concerning New Zealand Law and Policy Affecting Māori Culture and Identity (Wellington: Legislation Direct, 2011, vol. 1), 30. 


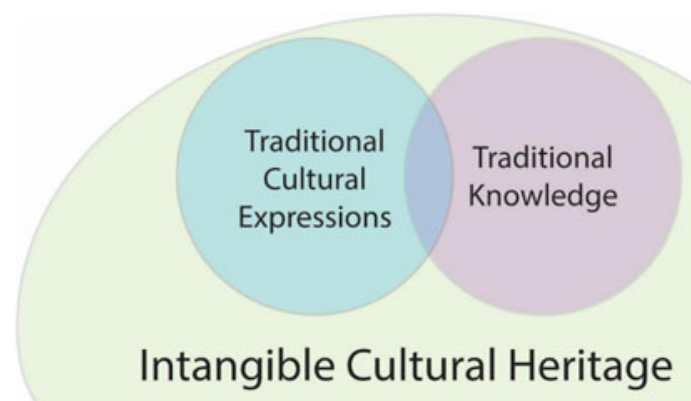

\section{Figure 2. The interrelation between intangible cultural heritage, traditional knowledge, and traditional cultural expressions}

knowledge appeared in relation to the protection of the environment. The Convention on Biological Diversity (CBD) (1992) was the first instrument to mention traditional knowledge in international law. ${ }^{25}$ From this inception, traditional knowledge has spread to other forums: the World Health Organization included traditional medicinal knowledge in its programs, article 9.2 of the International Treaty on Plant Genetic Resources for Food and Agriculture (2001) mentions traditional knowledge relevant to plant genetic resources for food and agriculture, etc. The phenomenon that caused traditional knowledge to be juridicized has been called "bio-piracy"; it is a bioprospecting practice in which pharmaceutical corporations patent an invention, which relies mainly on a community's traditional knowledge, usually associated with a genetic resource. Because of its genesis, the protection of traditional knowledge is strongly linked to the framework of the CBD and the two principles it enshrines, i.e. prior informed consent and the equitable sharing of benefits arising out of its utilization.

Traditional knowledge and traditional cultural expressions are neighboring concepts inextricably linked to each other. Traditional knowledge can have a cultural content and be used in connection with traditional cultural expressions. In these cases, traditional knowledge and traditional cultural expressions overlap. For instance, traditional knowledge relating to knitting, or dying techniques, can influence designs and patterns, which are traditional cultural expressions. ${ }^{26}$ In many cases, traditional knowledge does not have a cultural content, as it is mainly technical. As an example, the use of the Hoodia cactus originating in the Kalahari Desert as an appetite suppressant, by the San people, constitutes traditional knowledge, but it is not a traditional cultural expression. ${ }^{27}$

Cultural content also helps to delineate traditional cultural expressions from intangible cultural heritage. The Convention for the Safeguarding of the Intangible Cultural Heritage (2003) defines intangible cultural heritage as "practices, representations, expressions, knowledge, skills [...] that communities, groups and, in some cases, individuals recognise as part of their cultural heritage." 28 In other words, intangible cultural heritage is cultural heritage attached to people rather than to land. Intangible cultural heritage encompasses both traditional cultural expressions and traditional knowledge, but it is also a much broader category. It includes elements that are neither traditional cultural expressions nor traditional knowledge, such as foodways, like the Mediterranean diet, or social practices, like the Irrigators' tribunals of the Spanish Mediterranean coast. ${ }^{29}$ The following graph visually represents the interrelation between these three concepts.

${ }^{25}$ Article 8 (j) of the CBD.

${ }^{26}$ Michael Blakeney, "Protection of traditional knowledge by geographical indication," in Traditional Knowledge, Traditional Cultural Expressions and Intellectual Property Law in the Asia-Pacific Region, ed. Christoph Antons (Alphen aan den Rijn: Kluwer Law International, 2009), 105-106.

27 J. Michael Finger and Philip Schuler, Poor People's Knowledge Promoting Intellectual Property in Developing Countries, (Washington: The World Bank and Oxford University Press, 2004), 146.

${ }^{28}$ Art. 2.1 of the Convention for the Safeguarding of the Intangible Cultural Heritage.

${ }^{29}$ Both of these elements are inscribed on the UNESCO Representative List of the Intangible Cultural Heritage of Humanity. 


\section{ii. A Collective Essence}

Traditional cultural expressions are linked to a collective entity: a human group, a community, a minority, or indigenous people. The term "community" will be used hereafter to describe this entity. Traditional cultural expressions do not belong to an individual since they express a collective cultural identity. A community considers its traditional cultural expressions as an essential part of its cultural heritage; it identifies itself to them. The collective and anonymous nature of traditional cultural expressions is a challenge for intellectual property, which primarily recognizes individuals as right holders. In the case of the Tā Moko, this tradition belongs collectively to the Māori People, who consider it as taonga, a treasured possession. As a corollary, a practitioner could not claim sole ownership of Tà Moko.

\section{iii. Intergenerational Transmission}

The third key characteristic of traditional cultural expressions is that they are traditional, which means that they are transmitted from one generation to another inside a human group. Traditional cultural expressions extend in the present an intellectual activity of the past. They are at the same time ancient and contemporary. This traditional character resulting from intergenerational transmission differentiates traditional cultural expressions from the rest of the cultural expressions. Taking the example of Tā Moko, the Māori have transmitted this traditional cultural expression over centuries. Tā Moko has been documented as far back as the eighteenth century. ${ }^{30}$ In 1907 , the adoption of the Tohunga Suppression Act banned the practice and transmission of this discipline, endangering its viability. The Tā Moko was brought to the very brink of disappearing until it experienced a revival in the $1970 \mathrm{~s}^{31}$

Through the process of transmission, a special bond is formed between a community and its traditional cultural expressions. There is a strong feeling of belonging and affection between a community and its traditional cultural expressions. This bond is the reason why this legal concept has appeared in international intellectual property law.

\section{Why was this Legal Concept Introduced in International Intellectual Property Law?}

The notion of traditional cultural expression has appeared in international law as a response to commodification and commercial appropriation. When a traditional cultural expression is misused by a person outside of its community of origin, it can shake a community to its core. Because traditional cultural expressions are considered to be elements of the public domain, anyone can use them without having to seek the consent of the community at its origin. Users are not even required to share with the community the benefits arising from the use of a traditional cultural expression, even though the community has invested its resources to perpetuate it. Most of the time the name of the community that has created and transmitted the traditional cultural expression is not even mentioned by users. The community can perceive this as unethical, or even as unfair. Misappropriation of traditional cultural expressions is widespread. In the case of Tā Moko, French fashion designer Jean-Paul Gautier has used its patterns in advertising campaigns, without ever mentioning the Maori as its source or sharing benefits they provided.

In some cases, the traditional cultural expression is distorted or mutilated. The user modifies the traditional cultural expression without taking into account its meaning or the cultural values it expresses. The damage caused to the community is increased when the traditional cultural expression mutilated is sacred. In 2013, American company "Nike" commercialized women's sportswear inspired by traditional Polynesian tattoos. This product deeply offended the Samoan community as the patterns and the placement of the tattoos copied by Nike are reserved for men. The disregard for the customary rules regulating which gender was authorized to bear these tattoos caused an uproar forcing Nike to pull the sportswear. ${ }^{32}$

In some cases, the person, or the corporation, using the traditional cultural expression is granted an intellectual property right on the work incorporating it. For instance, American boxer Mike Tyson has a tattoo heavily

${ }^{30}$ Horatio Gordon Robley, Moko; or, Maori tattooing, (London: Chapman \& Hall, 1896), 2.

${ }^{31}$ Linda Nikora, Mohi Rua Waimarie, and Te Awekotuku Ngahuia, "Renewal and Resistance: Moko in Contemporary New Zealand," Journal of Community \& Applied Social Psychology, 17(2007): 479.

${ }^{32}$ Miranda Forsyth and Susan Farran, Weaving Intellectual Property Policy in Small Island Developing States, (Cambridge: Intersentia, 2015), 231-232. 
inspired by Tā Moko encircling his left eye. ${ }^{33}$ The tattoo artist who drew this design is American and has no relationship with the Māori. In the second movie of the Hangover franchise, one of the characters gets the exact same facial tattoo as Mike Tyson's. Since the tattoo artist had registered a copyright on this design; he was able to sue Warner Brothers for copying the tattoo. ${ }^{34}$ The tattoo artist claimed a copyright on the tattoo even though it was derivative of Tā Moko. In theory, the tattoo artist could sue Māori tattoo artists for practicing their art each time a design is substantially similar to Mike Tyson's.

In closing, the core issue is whether rights should be granted to communities so that they can control the use of their traditional cultural expressions. These rights would enable them to protect their economic and moral interests, and defend their traditional cultural expressions against the erroneous assertion of intellectual property rights. Still, a delicate balance must be found between protecting traditional cultural expressions and preserving the dynamic nature of culture, which requires interculturality, artistic freedom, and freedom of expression. Many art movements were born through cultural exchanges. When Japan put an end to its isolationist foreign policy, artists in Europe discovered Japanese woodblock prints, ukiyo-e, and started to collect them. ${ }^{35}$ Exposure to Japanese art profoundly influenced Impressionism. Protecting legally traditional cultural expressions could impede artists from borrowing elements from another culture and nip in the bud new art movements. If unbalanced rights were granted to communities on their traditional cultural expressions, it could, as a consequence, freeze or atrophy culture.

${ }^{33}$ Whitmill v. Warner Bros. Entm't, Inc., nº4:11-cv-00752 (E.D. Mo. Apr. 28, 2011).

${ }^{34}$ The case was settled outside of court, see Matthew Beasley, "Who owns your skin: intellectual property law and norms among tattoo artists," S. Cal. L. Rev, 85(2012), 1148.

${ }^{35}$ Frédéric Louis, Le Japon: Dictionnaire et Civilisation (Paris: Robert Laffont, 1996), 1173. 